\title{
Evaluating macroinvertebrate community shifts in the confluence of freestone and limestone streams
}

\author{
Jennifer K. HELLMANN, ${ }^{1,2 *}$ Jeffrey S. ERIKSON,${ }^{2}$ Simon A. QUEENBOROUGH ${ }^{1,3}$ \\ ${ }^{1}$ Department of Evolution, Ecology and Organismal Biology, The Ohio State University, Columbus, OH, USA; ${ }^{2}$ Department of \\ Biological Sciences, Messiah College, Mechanicsburg, PA, USA; ${ }^{3}$ School Forestry \& Environmental Studies, Yale University, New \\ Haven, CT, USA \\ *Corresponding author: hellmann.13@osu.edu
}

\begin{abstract}
Aquatic macroinvertebrates are critical to ecosystem functioning through their regulation of many essential top-down and bottom-up ecosystem processes such as energy translocation, nutrient flow, and detrital decomposition. However, specific preferences by macroinvertebrates for certain ranges of abiotic and biotic characteristics mean that changes in these factors often create large differences in benthic community structure. Investigations into drivers of community structure have found distinct patterns of variation between ecosystems, but drivers of macroscale variation may differ from drivers of microscale variation. Such microscale variation in macroinvertebrate community structure as a function of abiotic conditions may be found in the confluence of two geologically distinct freshwater streams. Variation in the origin, underlying bedrock, and watershed of a stream results in drastically different physical and chemical characteristics and correspondingly distinct macroinvertebrate community structures. In areas where water from geologically distinct streams flows together, a mixing zone emerges with unique chemical and physical characteristics. There is little information on how invertebrate communities are structured within this mixing zone. To investigate this, we examined how the structure of the macroinvertebrate community changed downstream of the confluence. Up to thirty metres downstream, we found distinct stream sections that mirrored physical and chemical conditions found in limestone and freestone streams, and a mixing zone with emergent properties. These physical and chemical changes between sites were accompanied by shifts in macroinvertebrate community composition. Diversity indices indicated significantly higher diversity in freestone sites than in limestone sites or the mixing zone and there was a unique composition of genera in the mixing zone that was distinct from both limestone and freestone sites. Factors driving variation in communities on a small-scale may be distinctly different from those influencing large-scale patterns and this study highlights the need for the continued exploration of the microscale variation in community structure.
\end{abstract}

Key words: Geology, diversity, microscale, abiotic, emergent, freshwater stream, limestone.

Received: December 2013. Accepted: July 2014.

\section{INTRODUCTION}

Aquatic benthic macroinvertebrates have traditionally been studied to monitor water quality and habitat health, particularly within freshwater systems (Metcalfe et al., 1989; Wallace and Webster, 1996). Their multiple life stages, sedentary nature, and varying tolerance levels to environmental stressors render them useful in assessing temporal and spatial changes within an aquatic ecosystem (Rosenberg and Resh, 1993, 1996). However, specific preferences for certain ranges of abiotic and biotic characteristics, such as velocity, $\mathrm{pH}$, substrate composition, and temperature, mean that changes in these factors often create large differences in benthic community structure even over small spatial scales (Williams and Mundie, 1978; Milner, 1987; Malmqvist et al., 1991; Covich et al., 1999; Grönroos and Heino, 2012).

A number of studies have examined the relationship between benthic communities and abiotic factors. Changes in substrate (Erman and Erman 1984; Rice et al., 2001, 2006), velocity (Habdija et al., 2004; Brooks et al.,
2005), and vegetation (Jackson et al., 2007) have all been highlighted as significant determinants of community structure, but mixed results from many studies (Hawkins et al., 1982; Erman and Erman, 1984; Moog and Janecek, 1991; Rice et al., 2001; Brooks et al., 2005) suggest that community shifts are most likely a result of the influence of multiple abiotic and biotic forces.

Geology affects multiple physical and chemical properties of aquatic systems, directly influencing channel bed material (Glazier and Gooch, 1987) and water chemical properties (Hynes, 1970; Johnson et al., 1997; Dow et al., 2006) as well as indirectly influencing discharge, topology, and vegetation (Cannan and Armitage, 1999). These physical and chemical changes due to geology have been shown to have corresponding effects on the biological community of the aquatic system (Glazier and Gooch, 1987; Dow et al., 2006; Kratzer et al., 2006; Neff and Jackson, 2011; Batzer and Ruhí, 2013). Streams of different geological origin have innately different levels of macroinvertebrate diversity. In comparison to sandstone or freestone-based streams, limestone streams tend to 
have naturally lower diversity, including reduced aquatic insect populations, and higher overall community density due to high abundances of tolerant species (Sutcliffe and Carrick, 1973; Krueger and Waters, 1983; Glazier and Gooch, 1987; Glazier, 1991; Ross et al., 2008; Botts, 2009; Neff and Jackson, 2011). This may be due to a number of characteristics that differ between the streams. Limestone streams often have more sand and silt based substrates, which can reduce diversity by diminishing substrate stability and decreasing the availability of colonisable habitat, refugia, and food availability (Glazier and Gooch, 1987; Harrison et al., 2004; Jähnig and Lorenz, 2008; Barnes et al., 2013). Additionally, the high alkalinity and conductivity inherent to limestone streams can decrease diversity, although these effects can be difficult to separate from high discharge and velocity (Neff and Jackson, 2011), which also can reduce diversity by diminishing colonisation ability (Townsend et al., 1997; Barquín and Death, 2004).

Although geology has been shown to play a role in producing variation in macroinvertebrate populations between streams, there is little knowledge about the influence of geology on community structure on smaller spatial scales. Geology may have a different effect on smaller spatial scales, where there are habitats of different chemical and physical properties available for colonisation within one area. We explored the influence of geology on community structure where streams merge and water from two distinct geological backgrounds (freestone and limestone) flow together to create a unique microhabitat that amalgamates properties from both streams. Areas immediately downstream of the confluence between two streams receive water, sediments, and organic material from both the main stem and the tributary draining into it, which have been shown to influence both the composition and the diversity of the macroinvertebrate community below the confluence (Rice et al., 2001; Kiffney et al., 2006; Grant et al., 2007; Collier and Lill, 2008; Mac Nally et al., 2011; Milesi and Melo, 2014). A potential change in macroinvertebrate community structure should be dependent on the characteristics of the streams that are converging (Rice et al., 2001). In the cases where the streams have distinctly different chemical and/or physical properties, there is the potential to have a unique microhabitat at the confluence, where the physical and chemical properties of both streams interact to form a distinct abiotic and biotic environment. Therefore, we sought to: i) evaluate if abiotic characteristics change at the point at which these two streams merge; ii) observe if and how the benthic community changes at the confluence; and iii) determine if the macroinvertebrates present in the mixing zone of the two streams are a true mix of the benthic communities from the two streams or represent a emergent community that is unique from one or both of the original streams.
Downstream of the confluence, we measured chemical and physical properties, as well as sampled macroinvertebrate populations, in areas with high flow from limestone streams, areas with high flow from freestone streams, and areas with flow from both streams. We predicted that chemical properties of the water below the confluence should be directly connected to the amount of water from freestone versus limestone streams; therefore, chemical properties of the mixing zone should be intermediate to either stream. We predicted that physical properties, including substrate and velocity, should also be intermediate in the mixing zone. Velocity should be dependent upon the initial flow rate of both streams and the ratio of tributary to mainstem flow. Substrate was also expected to be intermediate, as increased input of sand and silt in limestone streams was expected to mix with more gravel-based substrate in the freestone stream (Glazier and Gooch, 1987; Rice et al., 2001).

We predicted that physical and chemical shifts caused by geological differences in the stream should produce a distinct change in community structure. In particular, we expected a shift from amphipod-dominated communities in the sites that experience flow from the limestone streams to insect-dominated assemblages in the sites that have water flow primarily from freestone streams (North America: Glazier and Gooch, 1987; Glazier, 1991; Neff and Jackson, 2011; Europe: Smith et al., 2003; Barquín and Death, 2004), which is the same change in community composition we would expect if we analysed limestone and freestone streams separately. Diversity indices should indicate less diverse communities in limestone sites compared to freestone sites, as spring-fed streams often have naturally lower levels of diversity (Glazier and Gooch, 1987; Glazier, 1991; Barquín and Death, 2004). We predicted that intermediate physical and chemical levels in the mixing zone should co-occur with a macroinvertebrate community structure that is distinct from either Yellow Breeches or Trout Run, due to the strong match between the changes in the abiotic environment and shifts in macroinvertebrate communities (Palmer et al., 2000; Cottenie, 2005; Takao et al., 2008; Barnes et al., 2013; Heino, 2013).

\section{METHODS}

\section{Site selection}

The study site is located in Mechanicsburg, Pennsylvania, USA in Cumberland County and is directly downstream of the intersection of two streams: the Yellow Breeches, a freestone stream, and Trout Run, a limestone stream. The Yellow Breeches is a fifth order stream that flows $90 \mathrm{~km}$ through forest, cropland (dairy and agricultural), and residential areas until emptying into the Susquehanna River. Although it originates as a freestone stream 
in Michaux State Forest, it flows over a mix of sandstone/noncarbonate $(66 \%)$ and limestone bedrock $(34 \%)$ and its overall properties are influenced by this geology (Becher and Root, 1981; Chichester, 1996). While there are some deep pools (10-20 m) in earlier sections of the stream, the average depth in the stream is only $60 \mathrm{~cm}$ and the average discharge is $3.6 \mathrm{~m}^{3} \mathrm{sec}^{-1}$. Trout Run is a second order, limestone stream that originates $2 \mathrm{~km}$ before its confluence with Yellow Breeches; and it has an average depth of $25 \mathrm{~cm}$ and an average discharge of $0.83 \mathrm{~m}^{3} \mathrm{sec}^{-1}$. Like all limestone streams, Trout Run originates from limestone springs and is characterized by high alkalinity (>140 $\mathrm{mg} \mathrm{L}^{-1}$ ) and fairly constant temperatures year-round (Botts, 2009). Its land use history is similar to Yellow Breeches, as it runs primarily through cropland (dairy) and residential areas. As Trout Run (channel width $\sim 6 \mathrm{~m}$ ) merges into the Yellow Breeches (channel width $\sim 20 \mathrm{~m}$ ), water from Trout Run flows along the bank of the Yellow Breeches and slowly mixes with the water from Yellow Breeches nearer to the centre of the stream, creating a mixing zone where water from Trout Run and Yellow Breeches flow together. The two streams mix completely approximately $250 \mathrm{~m}$ downstream of the confluence, where the stream also undergoes changes in sediment and habitat.

Physical parameters and water chemistry were measured and macroinvertebrate samples were taken in March, May, and August 2010. Sampling occurred in the Yellow Breeches, at 10,20, and $30 \mathrm{~m}$ downstream of the intersection with Trout Run. At each of these distances, three sites were selected across the width of the Yellow Breeches to represent zones reflecting the abiotic characteristics of Trout Run and Yellow Breeches, as well as the

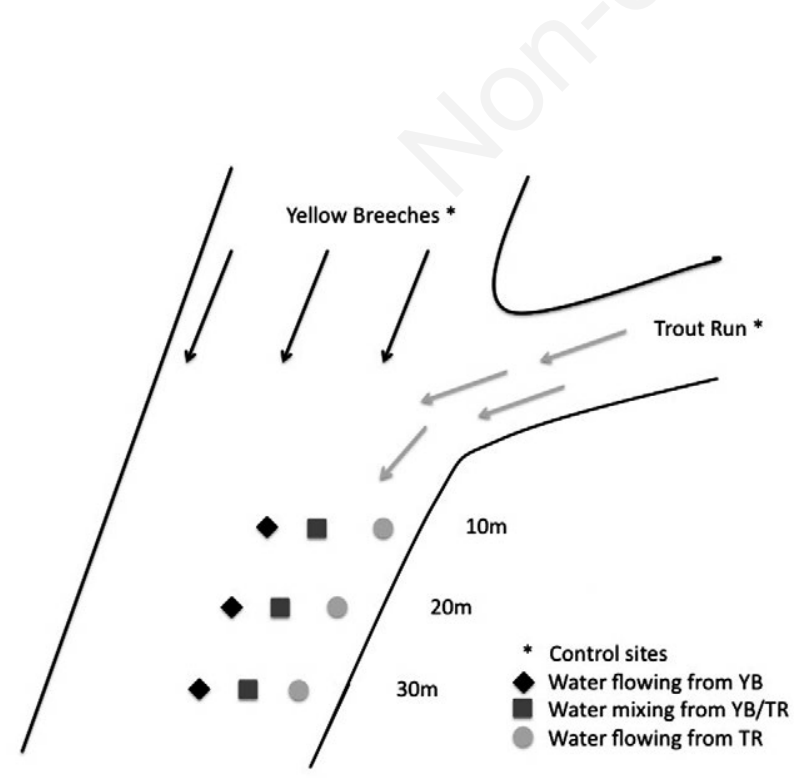

Fig. 1. Water flowing and mixing at the confluence of Yellow Breeches (freestone) and Trout Run (limestone). mixing zone (Fig. 1). Site location was chosen according to conductivity measurements; the conductivity of a stream is governed primarily by the geology over which it flows and therefore, is a reliable marker for distinguishing different streams (Grove, 1972; Neff and Jackson, 2011). The first set of sites was approximately one metre from the bank of the Yellow Breeches, where conductivity was comparable to upstream Trout Run (TR: $570-580 \mu \mathrm{S}$ $\mathrm{cm}^{-1}$; mean distance from the bank $0.88 \mathrm{~m} \pm 0.33 \mathrm{SD}$ ). Samples were also taken closer to the centre of the Yellow Breeches, at the point at which conductivity become comparable to upstream Yellow Breeches (YB: 230-240 $\mu \mathrm{S}$ $\mathrm{cm}^{-1}$; mean distance from the bank $5.66 \mathrm{~m} \pm 1.35 \mathrm{SD}$ ). Finally, samples were collected between these two sites, in the narrow range where conductivity was intermediate and where the water from both streams flowed together (mixing zone: $410-420 \mu \mathrm{S} \mathrm{cm}^{-1}$; mean distance from the bank $3.31 \mathrm{~m} \pm 1.13 \mathrm{SD}$ ). Therefore, we sampled at three distances $(10,20,30 \mathrm{~m})$ at each of the three sites (TR, YB, mixing zone) for a total of nine experimental samples (Fig. 1). Control samples were taken from Yellow Breeches and Trout Run streams above the confluence for baseline comparison.

\section{Physical and chemical data}

A physical assessment of the stream was performed at each collection site. We measured the following habitat parameters: conductivity $\left.(\mu \mathrm{S} \mathrm{cm})^{-1}\right)$, velocity $\left(\mathrm{cm} \mathrm{sec}^{-1}\right)$, depth $(\mathrm{cm})$, and substrate. Velocity and depth were assessed utilizing a General Oceanics flow meter (Miami, FL, USA). Velocity was measured halfway between the surface and the floor and the sample was averaged over a span of fifteen seconds to account for short-term fluctuations in flow. Substrate composition (\% boulder, cobble, gravel, sand, and silt) was measured via visual assessment over a $1 \mathrm{~m}^{2}$ area. Algal growth was negligible and was therefore not included as part of this study. Likewise, there was little riparian vegetation in the area sampled for this research and was considered to have minimal influence on the macroinvertebrate community structure. Water samples were taken from each site and preserved on ice until analysis within $24-48 \mathrm{~h}$ of collection. Nitrate, phosphorous, chloride, alkalinity, calcium hardness and hardness were measured $\left(\mathrm{mg} \mathrm{L}^{-1}\right)$ through a series of buret titrations and spectrometers. Techniques were performed according to the Water Analysis Handbook written by the purchasing company Hach, Loveland, CO, USA (http://www.hach.com/wah).

\section{Macroinvertebrate collection and classification}

Benthic macroinvertebrates were collected with standardized traveling kick samples. Procedures were performed according to the Rapid Bioassessment Protocol 
dictated by the Environmental Protection Agency (USA: Barbour et al., 1999). For each sample, jabs or kicks were taken over one minute from several different locations within $1 \mathrm{~m}^{2}$ and were collected using a D-net. Organisms and substrate were placed into a sorting tray and any organisms remaining on the net were removed with forceps and added to the sample. Vegetative debris was removed before transferring samples to $1 \mathrm{~L}$ containers and preserving the organisms in $70 \%$ ethanol. In the laboratory, all macroinvertebrates were separated from the surrounding substrate utilizing forceps and were classified to the genus level (Hawkins et al., 2000; Bailey et al., 2001; Lenat and Resh, 2001) utilizing taxonomic keys (Peckarsky et al., 1990; Merritt and Cummins, 1996) and a dissecting microscope. All pupae were discarded. Due to the difficulty of lower level identification in some families, organisms in the families Chironomidae, Lumbriculidae, and Lymnaeidae were identified to family level (Mac Nally et al., 2011). All organisms in the samples were identified; the full count method (as opposed to fixed count or coded abundance) allows for the most accurate estimate of abundance, density, and community composition of invertebrate samples (Wright et al., 1995; Courtemanch, 1996; Cao et al., 1998; Doberstein et al., 2000).

\section{Statistical analysis}

We calculated three estimators of the macroinvertebrate communities in each sample- taxa richness (number of taxa), EPT taxa richness (pooled taxa richness of the orders Ephemeroptera, Plecoptera, and Tricoptera), and Shannon index (an index that accounts for both the evenness as well as the diversity of species present). To compare the biological, physical and chemical characteristics of Yellow Breeches, Trout Run and the mixing zone, we used a linear mixed modeling approach. Sample time (i.e., samples from March, May and August) was treated as a random effect to account for pseudoreplication through time, and for each factor we compared a series of four nested models using likelihood ratio tests (Bolker et al., 2009). These models were i) a null model with no predictors; ii) a model including only river (Yellow Breeches, mixing zone, and Trout Run) to test for differences between experimental sites; iii) a model with river and distance from the confluence, to examine whether characteristics changed further from the confluence; and iv) a full model with the interaction between river and distance, to examine whether each river differed in its characteristics over distance. We also examined aggregated groups of species by functional feeding groups (Merritt and Cummins, 1996). Finally, we compared the invertebrate communities from each stream using principal components analysis (PCA) and Multivariate ANOVA (MANOVA).

PCA was also used to summarize and compare site en- vironmental conditions on the days that invertebrate samples were collected. Prior to PCA, a correlation matrix of the environmental variables was produced. Conductivity, alkalinity, hardness, calcium and chloride were all highly correlated ( $>0.9$ correlation coefficient), so only conductivity was used in the PCA. Further, depth and velocity were also highly correlated ( $>0.9$ correlation coefficient), and so only velocity was used in the PCA. Phosphorus was also excluded from this analysis because of missing data from one site. All samples were included in a single PCA. A total of seven physical and chemical variables were included in the PCA, standardizing all variables to unit variance.

Canonical correspondence analysis (CCA) was used to assess the relative importance of physical and chemical conditions in determining differences in invertebrate community structure between sites and distances. For the CCA, all data were analysed together; that is, the ordination captured both spatial (within and between sites) and temporal (between seasons) variation. The centre of the plot $(0,0)$ represents the average conditions summed across all samples. On a CCA biplot, the length of the arrow representing an environmental variable indicates the strength of the correlation between that variable and the ordination axes (McCune and Mefford 1995); the longer the arrow the stronger the relationship between a variable and the species data. In the current study, arrow lengths were used to make inferences about the relative importance of physical and chemical variables. All analyses were conducted in the software environment R 3.1.0 (R Core Team, 2014), using packages lme4 1.1-6 (Bates et al., 2014) and vegan 2.1-10 (Oksanen et al., 2013).

\section{RESULTS}

\section{Site characteristics}

In terms of biological characteristics, for all three taxa indices, the Yellow Breeches experimental sites showed double the number of taxa than Trout Run experimental sites (Fig. 2). These indices became closer further downstream, but models including distance were not significantly better than models with only river as the predictor (Tab. 1). Diversity in the mixing zone was intermediate to Yellow Breeches and Trout Run for all three indices. In terms of chemical characteristics, most measurements were significantly different between Yellow Breeches, Trout Run and the mixing zone (Tab. 1, indicated by significant likelihood ratio tests between the null model and model with river). Conversely to the biological parameters, conductivity, alkalinity, hardness, calcium and chloride were all significantly greater (generally double) in Trout Run than Yellow Breeches, with little variation downstream from the confluence (Fig. 2). Both phosphorus and nitrates showed a non-significant decrease with 
distance in Yellow Breeches, and a non-significant increase in Trout Run (Fig. 2), neither of which is great enough to result in a better model than the null (Tab. 1). Models including distance did not improve these basic models for any parameter. In terms of physical characteristics, velocity and depth were not significantly different between Yellow Breeches, Trout Run and the mixing zone, nor did they change with distance (Tab. 1, indicated by no significant difference between any model and the null model; Fig 2). In terms of substrate, there were significant changes in the proportions of cobble and gravel with distance between Yellow Breeches, Trout Run and the mixing zone. In Trout Run, the proportion of cobble decreased by two thirds between the control and $30 \mathrm{~m}$, while the proportion of gravel increased slightly, whereas in Yellow Breeches, proportions did not vary significantly
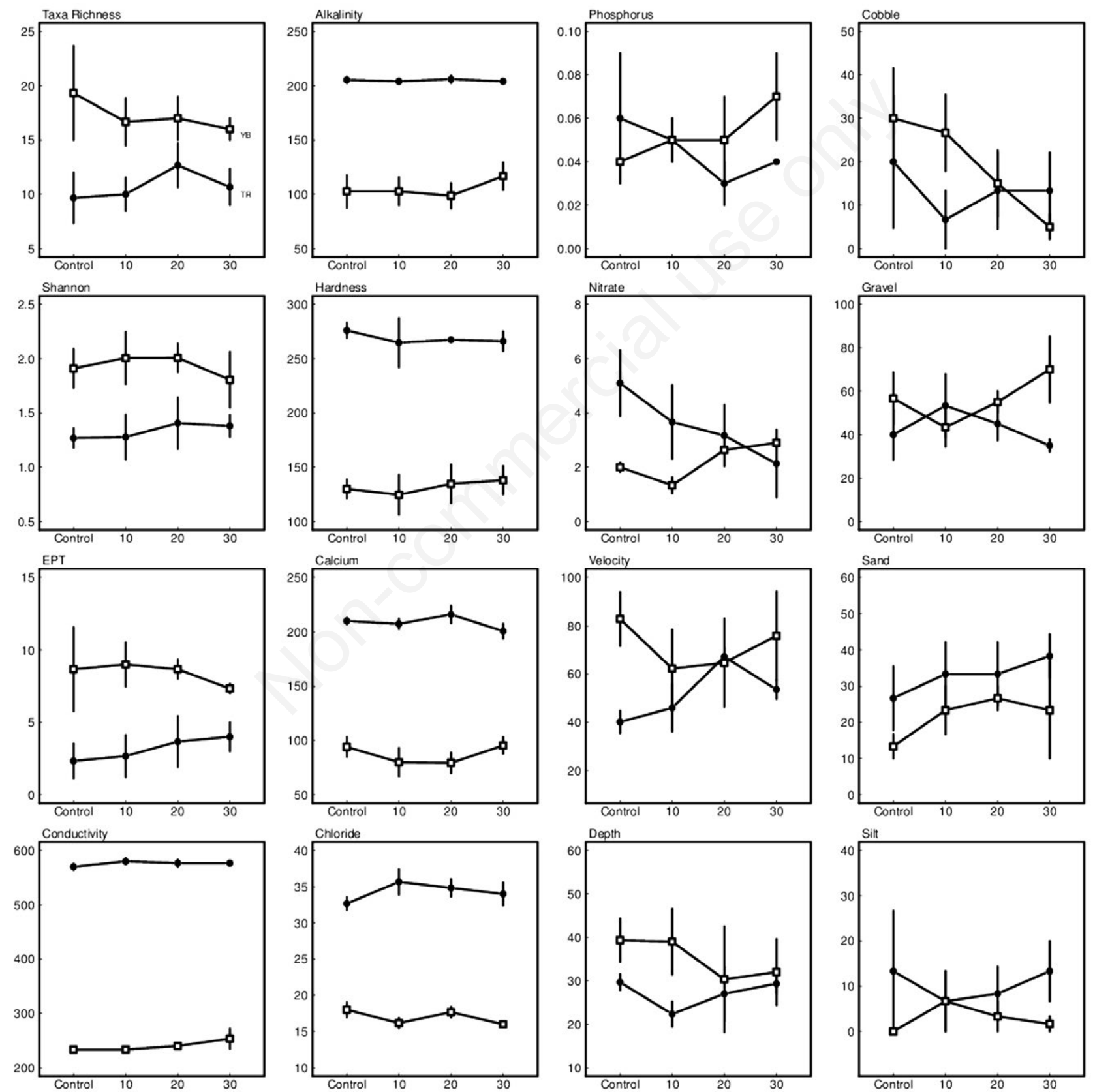

Fig. 2. Comparison of diversity, chemical values, and physical characteristics for Yellow Breeches (freestone; open squares) and Trout Run (limestone; solid circles) for the control sites as well as experimental sites at 10, 20, and $30 \mathrm{~m}$ from the confluence. 
over distance (Fig. 2). Proportions of sand showed no significant variation between experimental sites, but there was a higher proportion of silt in Yellow Breeches than Trout Run (Tab. 1, Fig. 2).

These differences between the experimental sites were highlighted in the PCA, with the mixing zone lying between Trout Run and Yellow Breeches (Fig. 3A). The first PCA axis separated the three rivers in terms of physical and chemical characteristics. Conductivity, nitrate and depth accounted for most of the variation (highest component loadings on Axis 1); alkalinity, calcium and chloride accounted for most of the variation along Axis 2. Site characteristics of the control sites were similar to those of the sites selected for sampling, confirming that our experimental sites were well placed in order to get the full range of environmental factors present within our sampling area (Fig. 2).

\section{Invertebrate community structure}

In total, 27 taxa (4638 individuals) were recorded from the experimental sites: 23 from the Yellow Breeches site (1535 individuals), 17 from the Trout Run site (1606 individuals), and 20 in the mixing zone (1497 individuals). We recorded a total of 50 genera in 13 families between the sampling sites and the control sites. As described above, Yellow Breeches had double the taxa richness, EPT index and Shannon index of Trout Run (Fig. 2, Tab. 1).

There were marked differences in the taxonomic composition of communities present in each river (Tab. 2). Chironomidae were more abundant in all sites, but more so in the mixing zone. Ephemerellidae, Elmidae, Lumbriculidae and Pleuroceridae were all more abundant in Yellow Breeches and mixing zone than Trout Run. Gammaridae were highly abundant in Trout Run, almost $500 \%$ more than Yellow Breeches. These differences in taxa are highlighted in the PCA (Fig. 3B), showing that a few key families and genera are much more abundant in specific streams, primarily Gammarus in Trout Run (PCA axis 1) and Chironomidae, Ephemerella and Leptoxis in Yellow Breeches (PCA axis 2). All other taxa were clustered together, showing little partitioning between streams. CCA of the invertebrate communities and the environmental data combined demonstrated distinct, but overlapping, clusters of the Yellow Breeches, Trout Run, and mixing zone sites. Velocity, conductivity, and substrate have the strongest effect on community composition (Fig. 3C). The effects of conductivity and velocity are mostly unrelated to each other, since they are at nearly right angles to each other; however, changes in gravel, nitrate, and velocity are correlated. The MANOVA supported this analysis, with an equivalent model to the PCA indicating that significant differences between rivers in community structure were driven by variation in physical factors (velocity and depth) and substrate rather than water chemistry (Tab. 2).

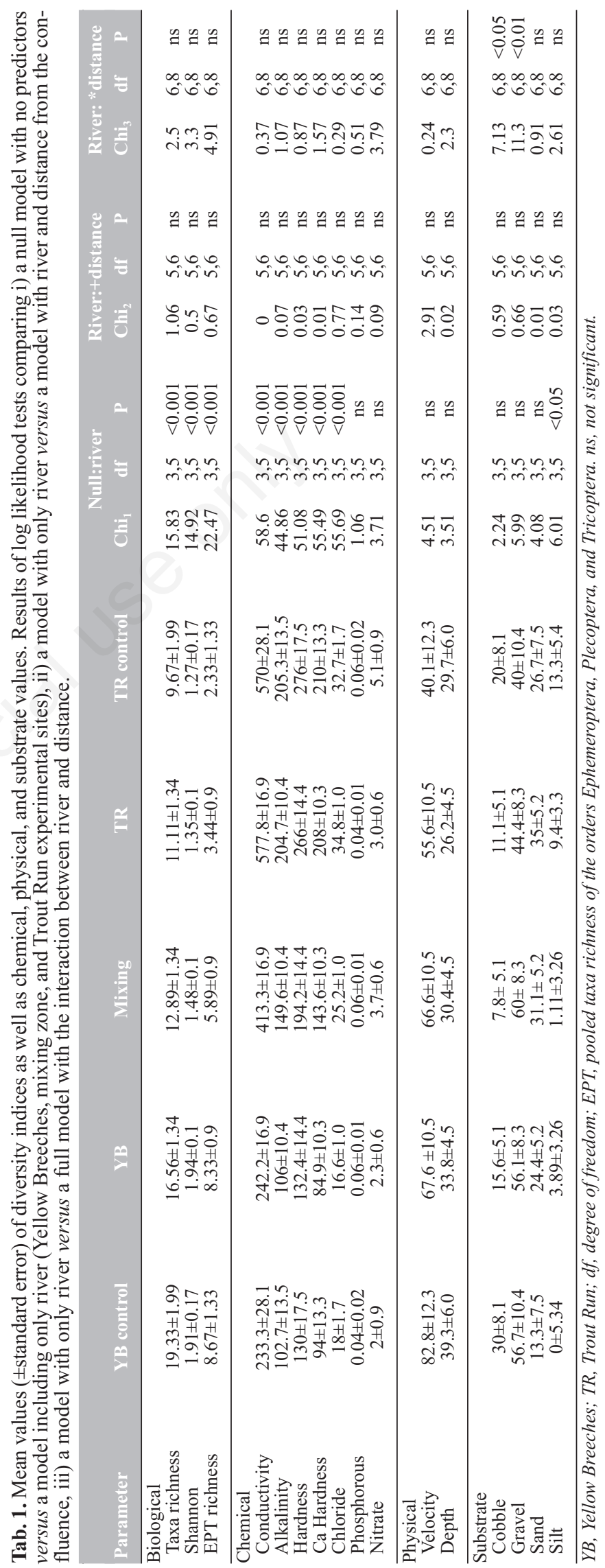


Feeding group composition was fairly constant throughout the sites, with no significant difference in communities between streams (Tab. 3). Of the five feeding groups- scrapers, collector-gatherers, predators, shredders, and filter-collectors, only collector-gatherers showed significant variation between the different sites (Fig. 4). Velocity was the major driver determining feeding group community structure, although there was also a significant, but weak effect of conductivity on feeding group community structure (Tab. 3).

\section{DISCUSSION}

We evaluated the changes in macroinvertebrate community structure that occur when chemical and physical variables shift as water from geologically distinct streams merge. As predicted, there were abiotic differences between Yellow Breeches (freestone), Trout Run (limestone), and mixing zone sites, particularly in chemical values such as alkalinity, hardness, calcium, and chloride. We found no significant differences in velocity and depth, and only minor differences in substrate composition. These abiotic changes between sites were accompanied by significant shifts in macroinvertebrate diversity and community composition. Similar to predictions, limestone streams had higher proportions of amphipod genera, such as Gammarus, and lower proportions of some orders of insects, including Ephemeroptera, Plecoptera, and Tricoptera. The mixing zone had intermediate levels of diversity compared to the limestone and freestone stream sites. Invertebrate communities within the mixing zone shared genera with both Trout Run and Yellow Breeches sites, but had a community structure that was distinct from either stream.

Despite significant changes in both community composition and diversity, there was little change in functional feeding groups. As feeding group composition is rarely, if ever, correlated with change in stream type (Archaimbault et al., 2005; Botts, 2009), it is unlikely that stream geology (the main driver of physical and chemical differences between streams in our study) strongly affects the factors that determine variation in feeding groups. In congruence with this idea, we found a significant, but weak effect of conductivity and correlated chemical variables on functional feeding group composition. In general, most changes in feeding group composition are associated with variation in food availability (Hawkins et al., 1982) and physical habitat (Wallace and Webster, 1996; Jowett, 2003). The small area in which these samples were taken had little to no algae and no obvious differences in riparian growth. As there was no change in depth and velocity between streams and only minimal substrate changes, it may be unlikely that there was much change in the types of specialized niches that were available in each experimental area. Instead, changes in velocity, which did not vary between streams, signifi-
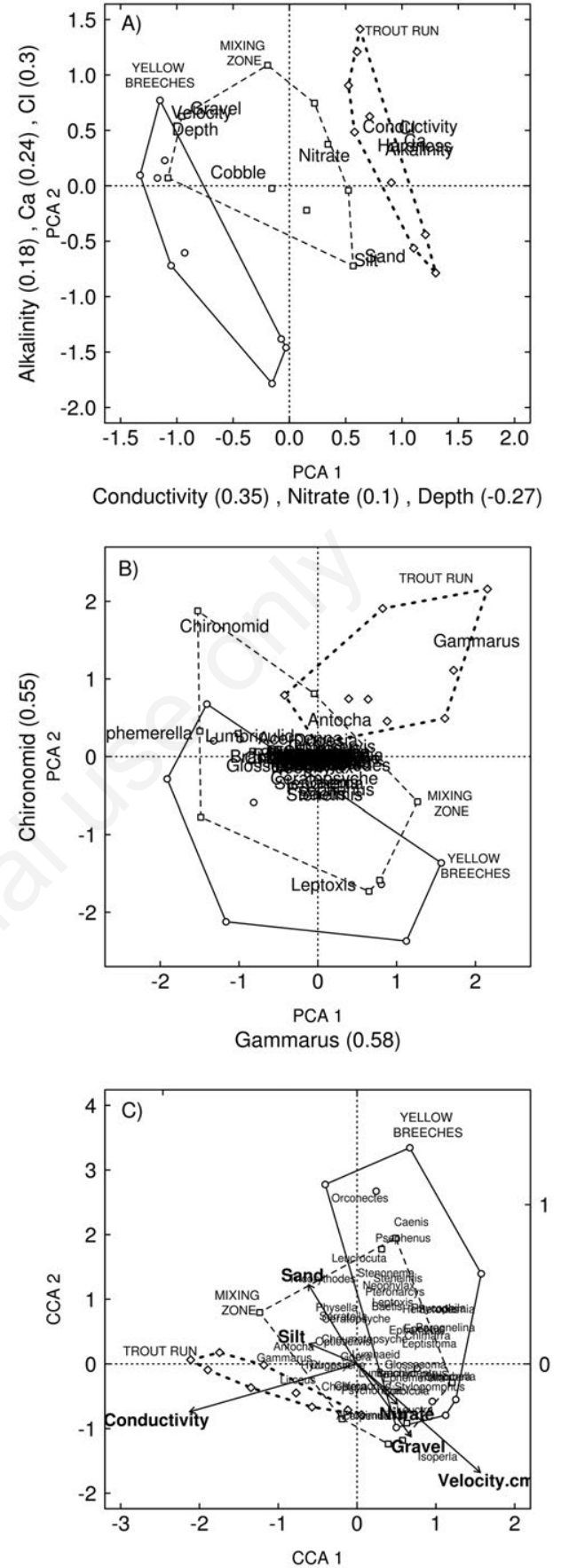

Fig. 3. A) PCA of chemical and physical characteristics of the confluence between a freestone stream (Yellow Breeches) and a limestone stream (Trout Run), and the mixing zone. All variables are scaled to unit variance. The mixing zone lies in between Yellow Breeches and Trout Run. Polygons group the experimental sites of the two source rivers (Yellow Breeches, squares with solid line; Trout Run, diamonds with dotted line) and the mixing zone (mixing zone, circles with dashed line). Control sites are indicated by the unfilled symbols. B) Principal components analysis of invertebrate communities in the confluence of a limestone (TR) and freestone (YB) stream. C) Canonical correspondence analysis ordinations of invertebrate communities and environmental (chemical and physical) variables. 
cantly predicted functional feeding group composition. It is possible that differences between streams could be due a transversal effect, where communities near the bank have a different structure than communities closer to the centre of the stream. This is commonly due to increases in depth, velocity, and substrate size as the distance from the bank increases (Bournaud et al., 1998; Jowett, 2003); however, we found no difference in depth and velocity between experimental sites and minimal changes in substrate. Differences in substrate composition (higher silt in sites near the bank) are also consistent with substrate commonly found in limestone streams (Glazier and Gooch, 1987; Harrison et al., 2004; Jähnig and Lorenz, 2008) and could have been a result of the sediment input that commonly occurs at the confluence of two streams (Rice et al., 2001, 2006). Additionally, as substrate had a fairly minimal impact on community structure compared to chemical values (Tab. 2), it is unlikely that transversal effects had a large impact on our results, which is consistent with other studies ( $\mathrm{Li}$ et al., 2001; Reid and Thomas, 2008).

Variation in macroinvertebrate community structure has previously been attributed to several different sources, including geographic location, interspecific interactions, and local environmental conditions. This study specifically controlled for geographic location, eliminating it as a potential source of community heterogeneity. We do not expect that interspecific competition or predation from higher-level organisms, such as fish (Nielsen et al., 1999;

Tab. 2. MANOVA table for a full model of invertebrate community structure in three different areas downstream from a confluence of two river types as a function of: i) river (Yellow Breeches, Trout Run, mixing zone) and distance from the confluence; and ii) chemical, physical and substrate parameters.

\begin{tabular}{|c|c|c|c|c|c|c|c|}
\hline Parameter & df & Sum of square & Mean square & F-stat & $\mathbf{R}^{2}$ & $\operatorname{Pr}(>\mathrm{F})$ & $\mathbf{P}$ \\
\hline \multicolumn{8}{|l|}{ Experimental sites } \\
\hline River & 2 & 0.95 & 0.48 & 3.05 & 0.21 & 0.003 & $<0.001$ \\
\hline Distance & 1 & 0.17 & 0.17 & 1.07 & 0.04 & 0.38 & \\
\hline River: distance & 2 & 0.16 & 0.08 & 0.52 & 0.04 & 0.89 & \\
\hline Residuals & 21 & 3.28 & 0.16 & & 0.71 & & \\
\hline \multicolumn{8}{|l|}{ Chemical/physical } \\
\hline Conductivity & 1 & 0.71 & 0.71 & 7.44 & 0.15 & $<0.001$ & $<0.001$ \\
\hline Nitrate & 1 & 0.18 & 0.18 & 1.94 & 0.04 & 0.06 & \\
\hline Velocity & 1 & 1.12 & 1.12 & 11.82 & 0.25 & $<0.001$ & $<0.001$ \\
\hline Depth & 1 & 0.23 & 0.23 & 2.41 & 0.05 & 0.02 & $<0.05$ \\
\hline Cobble & 1 & 0.21 & 0.21 & 2.20 & 0.05 & 0.04 & $<0.05$ \\
\hline Gravel & 1 & 0.13 & 0.13 & 1.39 & 0.03 & 0.19 & \\
\hline Sand & 1 & 0.18 & 0.18 & 1.88 & 0.04 & 0.08 & \\
\hline Residuals & 19 & 1.80 & 0.09 & & 0.39 & & \\
\hline
\end{tabular}

df, degree of freedom.

Tab. 3. MANOVA table for a full model of invertebrate community structure feeding groups in three different areas downstream from a confluence of two river types as a function of: i) river (Yellow Breeches, Trout Run, mixing zone) and distance from the confluence; and ii) chemical, physical and substrate parameters.

\begin{tabular}{|c|c|c|c|c|c|c|c|}
\hline Parameter & df & Sum of square & Mean square & F-stat & $\mathbf{R}^{2}$ & $\operatorname{Pr}(>\mathrm{F})$ & $\mathbf{P}$ \\
\hline \multicolumn{8}{|c|}{ Experimental sites } \\
\hline River & 2 & 0.18 & 0.09 & 1.13 & 0.09 & 0.35 & \\
\hline Distance & 1 & 0.06 & 0.06 & 0.79 & 0.03 & 0.53 & \\
\hline River: distance & 2 & 0.07 & 0.03 & 0.39 & 0.03 & 0.88 & \\
\hline Residuals & 21 & 1.77 & 0.08 & & 0.85 & & \\
\hline \multicolumn{8}{|l|}{ Chemical/physical } \\
\hline Conductivity & 1 & 0.14 & 0.14 & 2.79 & 0.07 & 0.045 & $<0.05$ \\
\hline Nitrate & 1 & 0.03 & 0.03 & 0.50 & 0.01 & 0.06 & \\
\hline Velocity & 1 & 0.69 & 0.69 & 13.26 & 0.33 & $<0.001$ & $<0.001$ \\
\hline Depth & 1 & 0.03 & 0.03 & 0.49 & 0.01 & 0.02 & \\
\hline Cobble & 1 & 0.07 & 0.07 & 1.41 & 0.04 & 0.04 & \\
\hline Gravel & 1 & 0.05 & 0.05 & 1.01 & 0.03 & 0.19 & \\
\hline Sand & 1 & 0.08 & 0.08 & 1.63 & 0.04 & 0.08 & \\
\hline Residuals & 19 & 0.98 & 0.05 & & 0.47 & & \\
\hline
\end{tabular}

df, degree of freedom. 
Helmus et al., 2013) or amphibians (Florencio et al., 2013), had a significant impact on the variation that we observed, as all sites in this study were exposed to the same population of these organisms. However, interspecific competition or predation between different species of macroinvertebrates cannot be conclusively eliminated as a source of variation in community structure. Competitive exclusion can influence macroinvertebrate communities (Gotelli and McCabe, 2002; Florencio et al., 2013) and the distribution of predator species can depend on the distribution of prey (Englund et al., 2009; Florencio et al., 2013). These effects may be stronger on smaller spatial scales, where there tends to be less spatial heterogeneity (Englund et al., 2009).

The effects of competitive exclusion and habitat segregation, when taxa segregate due to different preferences for non-overlapping habitats, are difficult to disentangle (Gotelli and McCabe, 2002). Nevertheless, interspecific interactions within macroinvertebrate communities are almost always influenced by abiotic changes in the environment (Florencio et al., 2013). There is strong evidence from numerous studies suggesting that community structure is primarily driven by the match between environmental conditions and niche requirements of the local species (Glazier and Gooch, 1987; Palmer et al., 2000; Cottenie, 2005; Takao et al., 2008; Barnes et al., 2013; Heino, 2013). Our results corroborate this evidence, as we found that chemical values, depth, velocity, and cobble

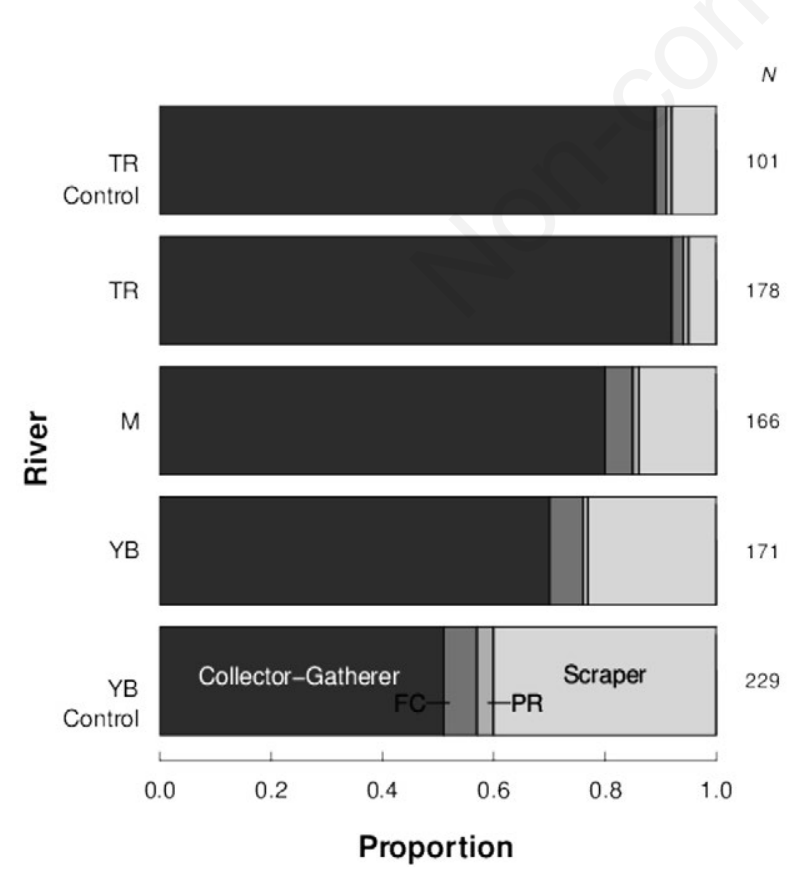

Fig. 4. Comparison of feeding groups among experimental sites and control sites. Data shown are mean proportions from each sample. substrate were significant predictors of macroinvertebrate community structure, while conductivity and velocity were significant predictors of functional feeding group composition.

\section{CONCLUSIONS}

Since there is little information available regarding macroinvertebrate community composition shifts as they pertain to the convergence of geologically distinct streams, we cannot extrapolate the findings of our study beyond our stream system. However, our data appear to be accordance with the community trends found in the few, more general comparisons made between limestone and freestone streams (Glazier and Gooch, 1987; Glazier, 1991; Barquín and Death, 2004). Continued studies exploring these microscale community changes due to geological differences would be helpful, as geological factors driving variation in communities on a small-scale may be distinctly different from those influencing large-scale patterns (Graça et al., 2004) and it is important to examine both levels of interactions to gain an understanding of how communities respond to geological differences on local and ecosystem levels (Downes et al., 1993; Boyero and Bailey, 2001; Boyero, 2003).

\section{ACKNOWLEDGMENTS}

This work was funded by the Department of Biological Sciences at Messiah College, Mechanicsburg, PA, USA. Thank you to Ian Hamilton, Erin Lindstedt, Isaac Ligocki, Elizabeth Hoskins, and three anonymous reviewers, for helpful comments on earlier versions of this manuscript.

\section{REFERENCES}

Archaimbault V, Usseglio-Polatera P, Bossche JV, 2005. Functional differences among benthic macroinvertebrate communities in reference streams of the same order in a given biogeographic area. Hydrobiologia 551:171-182.

Bailey R, Norris RH, Reynolds TB, 2001. Taxonomic resolution of benthic macroinvertebrate communities in bioassessments. J. N. Am. Benthol. Soc. 20:280-286.

Barbour MT, Gerritsen J, Snyder BD, Stribling JB, 1999. Rapid bioassessment protocols for use in streams and wadeable rivers: periphyton, benthic macroinvertebrates and fish. EPA/841-B-99-002. U.S. EPA, Office of Water, Washington.

Barnes JB, Vaughan IP, Ormerod SJ, 2013. Reappraising the effects of habitat structure on river macroinvertebrates. Freshwater Biol. 58: 2154-2167.

Barquín J, Death RG, 2004. Patterns of invertebrate diversity in streams and freshwater streams in Northern Spain. Arch. Hydrobiologia 161: 329-349.

Bates D, Maechler M, Bolker B, Walker S, Christensen RHB, Singmann H, 2014. Lme4: Linear mixed-effects models using Eigen and S4. R package version 1.1-6. Available from: http://cran.r-project.org/web/packages/lme4/

Batzer DP, Ruhí A, 2013. Is there a core set of organisms that 
structure macroinvertebrate assemblages in freshwater wetlands? Freshwater Biol. 58:1647-1659.

Becher AE, Root SI, 1981. Groundwater and geology of the Cumberland Valley, Cumberland County, Pennsylvania. U.S. Geological Survey Water-Resources Investigations Report 50.

Bolker BM, Brooks ME, Clark CJ, Geange SW, Poulsen JR, Stevens MHH, White J-SS, 2009. Generalized linear mixed models: a practical guide for ecology and evolution. Trends Ecol. Evol. 24:127-135.

Botts W, 2009. An index of biological integrity for 'true' limestone streams. Pennsylvania Department of Environmental Protection, Harrisburg, PA, USA.

Bournaud M, Tachet H, Berly A, Cellot B, 1998. Importance of microhabitat characteristics in the macrobenthos microdistributions of a large river reach. Ann. Limnol. 34:83-98.

Boyero L, 2003. Multiscale patterns of spatial variation in stream macroinvertebrate communities. Ecol. Res. 18: 365-379.

Boyero L, Bailey RC, 2001. Organization of macroinvertebrate communities at a hierarchy of spatial scales in a tropical stream. Hydrobiologia 464:219-225.

Brooks AJ, Haeusler T, Reinfelds I, Williams S, 2005. Hydraulic microhabitats and the distribution of macroinvertebrate assemblages in riffles. Freshwater Biol. 50:331-344.

Cannan CE, Armitage PD, 1999. The influence of catchment geology on the longitudinal distribution of macroinvertebrate assemblages in a groundwater dominated river. Hydrol. Process. 13:355-369.

Cao Y, Williams D, Williams NE, 1998. How important are rare species in aquatic community ecology and bioassessment? Limnol. Oceanogr. 43:1403-1409.

Chichester DC, 1996. Hydrogeology of, and simulation of ground-water flow in, a mantled carbonate-rock system, Cumberland Valley, Pennsylvania. U.S. Geological Survey Water-Resources Investigations Report 94-4090.

Collier KJ, Lill A, 2008. Spatial patterns in the composition of shallow-water macroinvertebrates communities of a large New Zealand river. New Zeal. J. Mar. Fresh. 42:129-141.

Cottenie K, 2005. Integrating environmental and spatial processes in ecological community dynamics. Ecol. Lett. 8:1175-1182.

Courtemanch DL, 1996. Commentary on the subsampling procedures used for rapid bioassessments. J. N. Am. Benthol. Soc. 15:381-385.

Covich AP, Palmer MA, Crowl TA, 1999. The role of benthic invertebrate species in freshwater ecosystems. BioScience 49:119-127.

Doberstein CP, Karr JR, Conquest LL, 2000. The effect of fixedcount subsampling on macroinvertebrate biomonitoring in small streams. Freshwater Biol. 44:355-371.

Dow CL, Arscott DB, Newbold JD, 2006. Relating major ions and nutrients to watershed conditions across a mixed-use, water-supply watershed. J. N. Am. Benthol. Soc. 25:887-911.

Downes BJ, Lake PS, Schreiber ESG, 1993. Spatial variation in the distribution of stream invertebrates: implications of patchiness for models of community organization. Freshwater Biol. 30:119-132.

Englund G, Johansson F, Olofsson P, Salonsaari J, Öhman J, 2009. Predation leads to assembly rules in fragmented fish communities. Ecol. Lett. 12:663-671.

Erman DC, Erman NA, 1984. The response of stream macroin- vertebrates to substrate size and heterogeneity. Hydrobiologia 108:75-82.

Florencio M, Gómez-Rodríguez C, Serrano L, Díaz-Paniagua $\mathrm{C}, 2013$. Competitive exclusion and habitat segregation in seasonal macroinvertebrate assemblages in temporary ponds. Freshwater Sci. 32:650-662.

Glazier DS, 1991. The fauna of North American temperate cold springs: patterns and hypotheses. Freshwater Biol. 26:527542.

Glazier DS, Gooch JL, 1987. Macroinvertebrate assemblages in Pennsylvania (U.S.A) springs. Hydrobiologia 150:33-43.

Gotelli NJ, McCabe DJ, 2002. Species co-occurrence: a metaanalysis of J.M. Diamond's assembly rules model. Ecology 83:2091-2096.

Graça MA, Pinto P, Cortes R, Coimbra N, Oliveira S, Morais M, Carvalho MJ, Malo J, 2004. Factors affecting macroinvertebrate richness and diversity in Portuguese streams: a two-scale analysis. Int. Rev. Hydrobiol. 89:151-164.

Grant EHC, Lowe WH, Fagan WF, 2007. Living in the branches: population dynamics and ecological processes in dendritic networks. Ecol. Lett. 10:165-175.

Grönroos M, Heino J, 2012. Species richness at the guild level: effects of species pool and local environmental conditions on stream macroinvertebrate communities. J. Anim. Ecol. 81:679-691.

Grove AT, 1972. The dissolved and solid load carried by some West African rivers: Senegal, Niger, Benue and Shari. J. Hydrol. 16:277-300.

Habdija I, Habdija BP, Matoničkin R, Kučinić M, Radanović I, Miliša M, Mihaljević Z, 2004. Current velocity and food supply as factors affecting the composition of macroinvertebrates in bryphyte habitats in karst running water. Biol. Brat. 59: 577-593.

Harrison SSC, Pretty JL, Shepherd D, Hildrew AG, 2004. The effect of instream rehabilitation structures on macroinvertebrates in lowland rivers. J. Appl. Ecol. 41:1140-1154.

Hawkins CP, Murphy ML, Anderson NH, 1982. Effects of canopy, substrate composition, and gradient on the structure of macroinvertebrate communities in cascade range streams of Oregon. Ecology 63:1840-1856.

Hawkins CP, Norris RH, Hogue JN, Feminella, JW, 2000. Development and evaluation of predictive models for measuring the biological integrity of streams. Ecol. Appl. 10:1456-1477.

Heino J, 2013. The importance of metacommunity ecology for environmental assessment research in the freshwater realm. Biol. Rev. 88:166-178.

Helmus MR, Mercado-Silva N, Jake M, Zanden V, 2013. Subsidies to predators, apparent competition and the phylogenetic structure of prey communities. Oecologia 173:997-1007.

Hynes HBN, 1970. The ecology of running waters. 1. University of Toronto Press: 555 pp.

Jähnig SC, Lorenz AW, 2008. Substate-specific macroinvertebrate diversity patterns following stream restoration. Aquat. Sci. 70:292-303.

Jackson HM, Gibbins CN, Soulsby C, 2007. Role of discharge and temperature variation in determining invertebrate community structure in a regulated river. River Res. Appl. 23:651-669.

Johnson LB, Richards C, Host GE, Arthur JW, 1997. Landscape 
influences on water chemistry in Midwestern stream ecosystems. Freshwater Biol. 37:193-208.

Jowett IG, 2003. Hydraulic constraints on habitat suitability for benthic invertebrates in gravel-bed rivers. River Res. Appl. 19:495-507.

Kiffney PM, Greene CM, Hall JE, Davies JR, 2006. Tributary streams create spatial discontinuities in habitat, biological productivity, and diversity in mainstem rivers. Can. J. Fish. Aquat. Sci. 63:2518-2530.

Kratzer EB, Jackson JK, Arscott DB, Aufdenkampe AK, Dow CL, Kaplan LA, Newbold JD, Sweeney BW, 2006. Macroinvertebrate distribution in relation to land use and water chemistry in New York City drinking-water-supply watersheds. J. N. Am. Benthol. Soc. 25:954-976.

Krueger CC, Waters TF, 1983. Annual production of macroinvertebrate in three streams of different water quality. Ecology 64:840-850.

Lenat DR, Resh VH, 2001. Taxonomy and stream ecology-The benefits of genus- and species-level identifications. J. N. Am. Benthol. Soc. 20:287-298.

Li J, Herlihy A, Gerth W, Kaufmann P, Gregory S, Urquhart S, Larsen DP, 2001. Variability in stream macroinvertebrates at multiple spatial scales. Freshwater Biol. 46:87-97.

Mac Nally R, Wallis E, Sam PS, 2011. Geometry of biodiversity patterning: assemblages of benthic macroinvertebrates at tributary confluences. Aquat. Ecol. 45:43-54.

Malmqvist B, Rundle S, Bronmark C, Erlandsson A, 1991. Invertebrate colonization of a new, man-made stream in southern Sweden. Freshwater Biol. 26:307-324.

McCune B, Mefford MJ, 1995. PC-ORD. Multivariate analysis of ecological data, ver. 2.0. MjM Software Design: 126 pp.

Merritt RW, Cummins KW, 1996. An introduction to the aquatic insects of North America. 3. Kendall/Hunt: 996 pp.

Metcalfe JL, 1989. Biological water quality assessment of running waters based on macroinvertebrate communities: history and present status in Europe. Environ. Pollut. 60:101-139.

Milesi SV, Melo AS, 2014. Conditional effects of aquatic insects of small tributaries on mainstream assemblages: position within drainage network matters. Can. J. Fish. Aquat. Sci. 71:1-9.

Milner AM, 1987. Colonization and ecological development of new streams in Glacier Bay National Park, Alaska. Freshwater Biol. 18: 53-70.

Moog O, Janecek BFU, 1991. River flow, substrate type and Hydrurus density as major determinants of benthic macroinvertebrate abundance, composition, and distribution. Int. Ver. Theor. Angew. 24:1888-1896.

Neff MR, Jackson DA, 2011. Effects of broad-scale geological changes on patterns in macroinvertebrate assemblages. J.N. Am. Benthol. Soc. 30:459-473.

Nielsen DL, Hillman TJ, Smith FJ, 1999. Effects of hydrological variation and plantivorous competition on macroinvertebrate community structure in experimental billabongs. Freshwater Biol. 42:427-444.

Oksanen J, Blanchet FG, Kindt R, Legendre P, Minchin PR, O'Hara RB, Simpson GL, Solymos P, Stevens MHH,
Wagner H, 2013. vegan: Community Ecology Package. R package version 2.0-10. Available from: http://CRAN.Rproject.org/package $=$ vegan

Palmer MA, Swan CM, Nelson K, Silver P, Alvestad R, 2000. Streambed landscapes: evidence that stream invergebrates respond to the type and spatial arrangement of patches. Lands. Ecol. 15:563-576.

Peckarsky B, Fraisseinet P, Penton M, Conklin D, 1990. Freshwater macroinvertebrates of Northeastern North America. 1. Cornell University Press: 456 pp.

R Core Team, 2014. R: A language and environment for statistical computing. $\mathrm{R}$ Foundation for Statistical Computing, Vienna, Austria.

Reid MA, Thomas MC, 2008. Surface flow types, near-bed hydraulics and the distribution of stream macroinvertebrates. Biogeoscience 5:1043-1055.

Rice SP, Ferguson RI, Hoey TB, 2006. Tributary control of physical heterogeneity and biological diversity at river confluences. Can. J. Fish. Aquat. Sci. 63:2553-2566.

Rice SP, Greenwood MT, Joyce CB, 2001. Tributaries, sediment sources, and the longitudinal organisation of macroinvertebrate fauna along river systems. Can. J. Fish. Aquat. Sci. 58:824-840

Rosenberg DM, Resh VH, 1993. Freshwater biomonitoring and benthic macroinvertebrates. 1. Chapman \& Hall: 488 pp.

Rosenberg DM, Resh VH, 1996. Use of aquatic insects in biomonitoring, p. 87-97. In: R.W. Merrit and K.W. Cummins (eds.) An introduction to aquatic insects of North America. Kendall/Hunt.

Ross RM, Long ES, Dropkin DS, 2008. Response of macoinvertebrate communities to remediation-simulating conditions in Pennsylvania streams influenced by acid mine drainage. Environ. Monit. Assess. 145:323-338.

Smith H, Wood PJ, Gunn J, 2003. The influence of habitat structure and flow permanence on invertebrate communities in karst spring systems. Hydrobiologia 510:53-66.

Sutcliffe DW, Carrick TR, 1973. Studies on mountain streams in the English Lake District. Freshwater Biol. 3:437-462.

Takao A, Kawagucki Y, Minagawa T, Kayaba Y, Morimoto Y, 2008. The relationships between benthic macroinvertebrates and biotic and abiotic environmental characteristics downstream of the Yahagi Dam, Central Japan, and the state change caused by inflow from a tributary. River Res. Appl. 24:580-597.

Townsend CR, Scarsbrook MR, Dolédec S, 1997. The intermediate disturbance hypothesis, refugia, and biodiversity in streams. Limnol. Oceangr. 42:938-949.

Wallace JB, Webster JR, 1996. The role of macroinvertebrates in stream ecosystem function. Annu. Rev. Entomol. 41:115-139.

Williams DD, Mundie JH, 1978. Substrate size selection by stream invertebrates and the influence of sand. Oceanogr. Limnol. 23:1030-1033.

Wright IA, Chessman BC, Fairweather PG, Benson LJ, 1995. Measuring the impact of sewage effluent on the macroinvertebrate community of an upland stream: the effect of different levels of taxonomic resolution and quantification. Aust. J. Ecol. 20:142-149. 